CLINICAL PRACTICE

\title{
From 'stepchild of primary healthcare' to priority programme: Lessons for the implementation of the National Integrated School Health Policy in South Africa
}

\author{
M Shung-King \\ Dr Maylene Shung-King is a postdoctoral fellow in the Health Economics Unit, School of Public Health and Family Medicine, \\ University of Cape Town, South Africa.
}

Corresponding author: M Shung-King (maylene.shungking@uct.ac.za)

In this article, I explore the South African 2003 National School Health Policy (NSHP) and the revised 2012 Integrated School Health Policy (ISHP). I examine whether the shortcomings in the development, content and implementation of the 2003 NSHP, and the context in which it was implemented, have been addressed adequately in the 2012 ISHP. The shortcomings include poorly structured relationships among key policy actors; an absent policy translation process resulting in insufficient understanding and prioritisation of school health by district and facility managers; and poor support and training of nurses. Insufficient capacity and resources, compounded by inadequate referral service capacity, resulted in the inequitable coverage and quality of the service and caused nurses to refer to school health as 'the stepchild of primary healthcare'. The comparison of the 2003 and 2012 policies is guided by the policy analysis framework of the Walt and Gilson policy triangle, which considers the policy context, process of policy development, policy actors and the policy content as key dimensions to successful policy development and implementation. I draw on an evaluation of a six-year implementation period (2003 - 2009) of the 2003 NSHP, which revealed the implementation challenges with the related explanatory factors. I provide lessons from the evaluation of the 2003 NSHP, highlight the policy changes in the new 2012 ISHP and finally highlight key opportunities, and remaining challenges, for the implementation of the new 2012 ISHP.

S Afr Med J 2013;103(12):895-898. DOI:10.7196/SAMJ.7550 


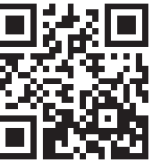

School health services aim to optimise the health of school-going children, by addressing health barriers to learning and thereby enhancing their learning potential. The South African (SA) school health service is a health promotion and preventive schoolbased service delivered to children who attend formal schools. It is part of a continuum of child healthcare, nestled between the early childhood years and adulthood. In the absence of good early childhood services, school health services provide a safety net for children who missed out on early childhood interventions. By promoting healthy lifestyles, and attending to psychosocial and chronic physical health conditions, it prepares children for healthier adulthoods.

SA school health services have several key components: (i) a health assessment, whereby children are screened for a number of health conditions such as vision and hearing; (ii) health education and health promotion, age-appropriately tailored; (iii) psychosocial and mental health assessments; (iv) the identification and support of children with chronic health conditions; $(v)$ facilitating the creation of safe and healthy school environments; (vi) preventive interventions, mainly immunisations and deworming (the provision of sexual and reproductive preventive services at school is still under contestation); and (vii) addressing minor ailments.

Importantly, school health services are delivered by the National Department of Health (NDoH), in the domain of the Department of Basic Education (DoBE), and require the Department of Social Development (DoSD) to address learners' social challenges, thus requiring a structured collaboration between these three government departments. Given the high primary school enrolment figures for SA, school health interventions have the potential to reach nearly 12 million children and achieve close to $100 \%$ service coverage given the accessibility of children in schools.

\section{History}

In the apartheid era, school health services were characterised by racial, socioeconomic and geographic inequity, with nonstandardised delivery modes across areas. ${ }^{[1-3]}$ They operated as a 'vertical' programme, with little articulation with other child health services. ${ }^{[4,5]}$ These deficiencies prompted the development of the first National School Health Policy (NSHP) in 2003, ${ }^{[6]}$ which emphasised the integration of school health services with other district health services. However, many challenges marred the development and implementation of the 2003 NSHP, as revealed in an evaluation conducted six years after the policy's release in 2009. ${ }^{[7,8]}$ These implementation challenges prompted the current Minister of Health $(\mathrm{MoH})$ to prioritise school health in primary healthcare (PHC) reforms and resulted in a revised Integrated School Health Policy (ISHP) in 2012. ${ }^{[9]}$

Three key failures characterised the performance of the 2003 NSHP: (i) low service provision coverage across most districts, as measured by coverage of grade 1 health assessments; (ii) suboptimal and inequitable nurse to school ratios; and (iii) the absence of referral services to respond to problems identified through the screening assessments. Disaggregated district coverage data from the 2009 evaluation showed that coverage was as low as $10 \%$ in some subdistricts. ${ }^{[7,8]}$ Only a few areas attained $100 \%$ coverage, meaning that all schools within that catchment area had grade 1 health assessments done within a given year. Nurse to school ratios varied from as high as 1:8 in one sub-district to as low as 1:357 in another sub-district. These ratios meant that schools would be visited approximately once every five years at best. The average nurse to school ratio was 1:20 - 1:30.
Lack of transport for nurses to schools compounded the situation. Many children reportedly were unable to access referral services such as optometry and dentists due to their unavailability, distant location and prohibitive transport costs. Nurses also could not follow-up children who were identified with problems.

The 2009 evaluation found that district managers who allocated the PHC budgets and PHC and facility managers who oversaw the training, supervision and support of school health teams were key to its implementation. The general lack of managerial understanding and appreciation of school health resulted in poor managerial support, which thwarted successful implementation. Pockets of good practice were mainly due to the passion and commitment of individual nurses. The fledgling nature of the district health system in most provinces compounded implementation challenges.

\section{Comparing the 2003 and 2012 policies}

The analysis of the 2003 and 2012 policies draws on the policy triangle framework, ${ }^{[10]}$ which considers four dimensions of policies: the context in which policies are developed and implemented; the process of policy development; the policy content; and the key policy actors. The analysis is complemented by my insights based on my longstanding engagement with school health, including participation in development and evaluation of the 2003 NSHP. Pertinent differences between the two policies are summarised in Table 1 and the implications of these for the 2012 ISHP implementation are highlighted.

The 2012 ISHP is fundamentally similar to its predecessor in its content, but differs in high-level support, the overall implementation context and in the strength of key relationships, in particular that between health and basic education. As a lack of proper intersectoral collaboration was a key explanatory factor for the 2003 NSHP implementation failure, ${ }^{[7,8]}$ the fundamental premise of the 2012 ISHP is the collaboration between the NDoH, DoBE and DoSD. It further requires good integration between various programmes within the $\mathrm{NDoH}$ - hence the title 'Integrated School Health Policy'.

Passion, power and politics are commonly identified as key influences in policy-development processes. ${ }^{[1-13]}$ The passion of the $\mathrm{MoH}$ has been a key driver in reigniting a national interest in school health, demonstrating the effectiveness of powerful policy champions in determining policy agendas. However, this is not the only factor. The school health agenda is aided by its location within broader healthcare reform initiatives. The international focus on maternal and child health and the looming deadline of the Millennium Development Goals in 2015 further contributes to the renewed emphasis on child health in SA. School health has also received fresh attention globally, with many countries attempting to revive and strengthen this service. ${ }^{[14]}$ Beyond the powerful champion, designated school health persons in health and education at a national, provincial and district level are key to furthering the school health agenda - a feature that was largely absent in the 2003 implementation period.

\section{Opportunities and residual challenges}

The school health service provides opportunities for exploring new and innovative ways of delivering a truly integrated service across several government departments, non-governmental and community-based agencies, where resources are pooled, planning is integrated and where the responsibility for the service is shared. Currently the DoBE already has many policies and programmes with some health orientation. Educators have at least 1000 contact hours with learners per year and non-governmental agencies in many areas similarly spend significant time in schools. Co-ordinating all 
Table 1. Key differences in the 2003 NSHP and the 2012 ISHP

\begin{tabular}{|c|c|c|}
\hline & 2003 NSHP $^{*}$ & 2012 ISHP $^{\dagger}$ \\
\hline \multirow[t]{2}{*}{ Political support } & $\begin{array}{l}\text { Weak - low level of support from the } \mathrm{MoH} \text { and } \\
\text { none from the MoBE }\end{array}$ & $\begin{array}{l}\text { Strong - school health featured consistently in the State of the } \\
\text { Nation address since } 2010 \text {; strongly supported by } \mathrm{MoH} \text { and } \\
\text { MoBE who co-signed the policy } \\
\text { In-principle support from various national education bodies } \\
\text { at the launch of the } 2012 \text { policy }\end{array}$ \\
\hline & No media attention & $\begin{array}{l}\text { Much media publicity, especially regarding sexual and } \\
\text { reproductive health aspects } \\
\text { President, MoH and MoBE attended the launch }\end{array}$ \\
\hline Context & $\begin{array}{l}\text { One of many child health polices developed in } \\
\text { post-apartheid period, and relatively low priority } \\
\text { v. other child health issues } \\
\text { Fledgling district health system with many } \\
\text { challenges }\end{array}$ & $\begin{array}{l}\text { Renewed health system reform efforts, with school health as } \\
\text { one of several priority streams of district level PHC reforms }\end{array}$ \\
\hline \multicolumn{3}{|l|}{ Relationships between: } \\
\hline Sectors & $\begin{array}{l}\text { Tri-sectoral policy task team, with health the } \\
\text { only active member }\end{array}$ & $\begin{array}{l}\text { Tri-sectoral policy task team, with } \mathrm{NDoH} \text { and DoBE active } \\
\text { partners; social development significantly less involved }\end{array}$ \\
\hline $\begin{array}{l}\text { Various programmes } \\
\text { in health }\end{array}$ & $\begin{array}{l}\text { Inadequate co-ordination, in particular between } \\
\text { school health and health promoting schools }\end{array}$ & $\begin{array}{l}\text { Co-ordination between various health programmes not yet } \\
\text { optimal }\end{array}$ \\
\hline Leadership capacity & $\begin{array}{l}\text { National and provincial school health } \\
\text { co-ordinator positions largely vacant for first } \\
5 \text { years of implementation }\end{array}$ & $\begin{array}{l}\text { Designated national, provincial and district school health role } \\
\text { players in health and education largely in place }\end{array}$ \\
\hline \multicolumn{3}{|l|}{ Health service package } \\
\hline Health assessment & $\begin{array}{l}\text { Mainly for grades } 1 \text { and } \mathrm{R} \text {, roughly } 1 \text { million } \\
\text { learners per year } \\
\text { Disadvantaged schools had to be prioritised, but } \\
\text { not done in a structured way }\end{array}$ & $\begin{array}{l}\text { Expanded to } 1 \text { year in each educational phase, grade } \mathrm{R} / 1,4,8 \\
\text { and } 10 \text {; close to } 4 \text { million learners per year } \\
\text { Quintile one and two schools purposively prioritised }\end{array}$ \\
\hline Health promotion & $\begin{array}{l}\text { Across all grades, but primarily in primary } \\
\text { schools }\end{array}$ & $\begin{array}{l}\text { Across all grades; new focus on sexual and reproductive } \\
\text { health, and risk behaviour in secondary schools }\end{array}$ \\
\hline $\begin{array}{l}\text { Prevention and clinical } \\
\text { care }\end{array}$ & $\begin{array}{l}\text { Deworming } \\
\text { TD vaccine introduced } 6 \text { years into the } \\
\text { implementation period }\end{array}$ & $\begin{array}{l}\text { Deworming and TD vaccination for } 6 \text { and } 12 \text {-year-olds } \\
\text { Contestation on the provision of contraception in schools } \\
\text { Possibility of introducing the HPV vaccine for young girls }\end{array}$ \\
\hline $\begin{array}{l}\text { Psychosocial and mental } \\
\text { health }\end{array}$ & $\begin{array}{l}\text { Assessments to be introduced only if provinces } \\
\text { had the necessary capacity }\end{array}$ & Assessments now a requirement \\
\hline Chronic diseases & $\begin{array}{l}\text { Mentioned, but no specific implementation } \\
\text { direction }\end{array}$ & $\begin{array}{l}\text { Identification and support of children with chronic diseases a } \\
\text { required part of the service }\end{array}$ \\
\hline $\begin{array}{l}\text { Interaction with school } \\
\text { community, educators, } \\
\text { parents, and caregivers }\end{array}$ & $\begin{array}{l}\text { Left to individual nurses and school health teams } \\
\text { to negotiate with schools, with mostly poor } \\
\text { co-ordination } \\
\text { Multi-partner teams to be established at district } \\
\text { level for co-ordinated planning of school-based } \\
\text { interventions }\end{array}$ & $\begin{array}{l}\text { More structured between health and education } \\
\text { Community-based implementation teams in health and } \\
\text { school-based teams required to work together } \\
\text { Multi-partner teams to be established at district level for } \\
\text { co-ordinated planning of school-based interventions }\end{array}$ \\
\hline \multicolumn{3}{|l|}{ Key resources } \\
\hline Staff & $\begin{array}{l}\text { Districts to fund school health posts entirely out } \\
\text { of existing budgets } \\
\text { Staff support and training left to districts }\end{array}$ & $\begin{array}{l}\text { National grants made available to support the recruitment of } \\
\text { additional nurses for school health } \\
\text { Standardised training manual for nurses and educators } \\
\text { developed; initial training supported from the national level }\end{array}$ \\
\hline Transport & $\begin{array}{l}\text { Mostly shared with other outreach services and } \\
\text { often unavailable for school health }\end{array}$ & $\begin{array}{l}\text { Mobile vehicles equipped for eye, dental and general primary } \\
\text { level care provided to } 10 \mathrm{NHI} \text { pilot sites, specifically for } \\
\text { school health services } \\
\text { Providing transport incumbent on other districts }\end{array}$ \\
\hline Monitoring and evaluation & Poor - inappropriately aggregated indicators & Indicators still under construction \\
\hline
\end{tabular}


these available resources towards a single goal of maximising the holistic health and wellbeing of learners is therefore essential. It requires effective communication, planning and optimising existing structures to facilitate this level of integration.

Potential pitfalls identified in the 2009 evaluation require consideration. The dependence of the 2003 NSHP's successful implementation on individuals rather than on a good system, as identified in the 2009 evaluation, highlights two issues: the importance of considering the implementation context prior to releasing a new policy; and having a structured policy translation process, whereby implementers have the benefit of developing a shared understanding and common vision of the policy and work out a joint plan of how to implement it. For school health, it requires a process whereby a common understanding and vision for the school health service is developed with all role players who are at the forefront of managing, delivering and receiving the school health service. This essential process will require concerted leadership from the designated school health leaders at all levels.

The attention and resources currently bestowed upon school health have the potential of recreating a 'vertical' focus, possibly at the expense of other primary level services. On the other hand, considering its relative neglect in the past, this focused attention may help to establish it properly alongside all other PHC services. The prioritisation of quintile one and two schools by the 2012 ISHP potentially will ameliorate the low coverage and narrow the inequity gap. However, the expanded scope of the service package might eliminate this advantage, as the expectations of school health teams may be too high.

The absence and inaccessibility of referral services remain a concern, as the greatest share of the school health service package constitutes health-screening assessments. ${ }^{[9]}$ Mass population screening programmes require referral services that are able to respond to any identified problems. ${ }^{[15,16]}$ In the absence of such services, the utility and ethics of screening become questionable. The significant expansion in the 2012 ISHP of both the numbers of children that should be screened and the conditions which they must be screened for, therefore require careful contemplation and planning, as referral services will take a long time to catch up with the demand from increased screening outputs. Furthermore, the best time to screen for certain childhood conditions is in early childhood, where the impact on physical and cognitive development is at its maximum. The relative balance given to screening in early childhood developmental services v. school health services must therefore be considered.

\section{Conclusion}

The ultimate success of the school health service will depend on: (i) prioritising the interventions that can make the greatest difference to children's health and well-being, within the current resource constraints, with due consideration of the role and responsibilities of each sector so as to foster the best implementation context; (ii) appropriately capacitating the frontline role players to execute their due responsibilities; and (iii) developing processes that foster sustainable collaborations between key role players.

1. Coovadia H, Jewkes R, Barron P, et al. The health and health system of South Africa: Historical roots of current public health challenges. Lancet 2009;374(9692):817-834. [http://dx.doi.org/10.1016/S01406736(09)60951-X

2. Savage M. Building health services for a post-apartheid era. Issue: A Journal of Opinion 1990;18(2):2428. [http://dx.doi.org/10.2307/1166378]

Price M. Health care as an instrument of apartheid policy in South Africa. Health Policy and Planning 1986;1(2):158-170. [http://dx.doi.org/10.1093/heapol/1.2.158]

Abrahams E, Wigton A. Workshop on an Integrated Policy for School Health. Proceedings. Cape Town: Child Health Policy Institute, 1997.

5. Abrahams E, Wigton A, de Jong R. Workshop on an Integrated Policy for School Health. Discussion Document. Cape Town: Child Health Policy Institute, 1997.

6. National Department of Health. The National School Health Policy and Implementation Guidelines. National Department of Health. The

7. Shung-King M. Why child health policies in post-apartheid South Africa had not performed a 7. Shung-King M. Why child health policies in post-apartheid South Africa had not pe
intended. The Case of the School Health Policy. DPhil thesis, 2012. Oxford University, UK.

8. Shung-King M. Review Report: Implementing the National School Health Policy in South Africa, 2003-2009.

9. National Department of Health. The Integrated School Health Policy. Pretoria: Government Printer, 2012.

10. Walt G, Gilson L. Reforming the health sector in developing countries: The central role of policy analysis. Health Policy and Planning 1994;9(4):353-370. [http://dx.doi.org/10.1093/heapol/9.4.353]

11. Erasmus E, Gilson L. How to start thinking about investigating power in the organizational settings of policy implementation. Health Policy and Planning 2008;23(5):361-368. [http://dx.doi.org/10.1093/ heapol/czn021]

12. Gottweis H. Rhetoric in Policy Making: Between Logos, Ethos and Pathos. In: Fischer F, Miller GJ, Sidney MS, eds. Handbook of Public Policy Analysis. Theories, Politics and Methods. Boca Raton: CRC Press, 2007.

13. Walt G. Health Policy: An Introduction to Process and Power. London: Zed Books, 1994

14. Bundy D. Rethinking School Health: A Key Component of Education for All. Washington: The International Bank for Reconstruction and Development, The World Bank, 2011.

15. Wilson JMG, Junger G. Principles and Practice of Screening for Disease. Geneva WHO, 1968. http:// whqlibdoc.who.int/php/WHO_PHP_34.pdf (accessed 5 November 2013).

16. Andermann A, Blancquaert I, Beauchamp S, Dery V. Revisiting Wilson and Junger in the genomic age: A review of screening criteria over the past 40 years. Bull World Health Organ 2008;86(4):317-319. [http://dx.doi.org/10.2471/BLT.07.050112]

Accepted 30 September 2013. 